\title{
Signet Ring Cell
}

National Cancer Institute

\section{Source}

National Cancer Institute. Signet Ring Cell. NCI Thesaurus. Code C12487.

A neoplastic cell containing cytoplasmic mucin. The presence of mucin pushes the

nucleus of the cell to the periphery, assuming a configuration resembling a signet ring. 